\title{
Use of a clinical cell flow cytometer for differential counts of prawn Penaeus monodon haemocytes
}

\author{
Leigh Owens*, Antoinette O'Neill
}

Department of Microbiology and Immunology, PO James Cook University of North Queensland 4811, Australia

\begin{abstract}
Flow cytometry (FC) has been used extensively for monitoring human blood cell populations and it would be useful if this technology could be applied to the analysis of prawn haemocytes. This paper shows that the Cell-Dyn 3000 flow cytometer can distinguish haemocyte types from Penaeus monodon and then describes the range of haemocyte counts within normal prawns. The total haemocyte count was $23.3 \times 10^{6}$ cells $\mathrm{ml}^{-1}$ using a haemocytometer and $21.0 \times 10^{6}$ cells $\mathrm{ml}^{-1}$ with the FC. With light microscopy, nongranular, small-granular and large-granular haemocytes were $82.7 \pm 14$, $15.6 \pm 17$, and $1.7 \pm 2 \%$ respectively of the cell types, whilst with FC, the proportions were $82.6 \pm 17$, $14.5 \pm 15$, and $2.9 \pm 3 \%$ respectively. Neither age, weight, carapace length nor population source had any significant effect ( $p>0.05$ ) on total or differential haemocyte counts. However, sex had a significant effect $(p<0.05)$ and once sexual dimorphism, as measured by total length, had occurred in the prawn population, females showed increased nongranular haemocyte counts $(F=4.56, \mathrm{df}=1,39, \mathrm{p}<$ $0.05)$ and, consequently, total haemocyte counts $(F=4.60, \mathrm{df}=1,39, p<0.05)$. The third sequential bleeding of prawns $\left(0.1 \mathrm{ml}\right.$ of haemolymph bleed $\left.{ }^{-1}\right)$ produced a significant decrease in total haemocyte numbers with proportional increases in granular haemocytes.
\end{abstract}

KEY WORDS: Penaeus monodon - Flow cytometry · Haemocyte counts - Disease studies

\section{INTRODUCTION}

Penaeus monodon is grown in aquaculture exten. sively throughout the Indo-west Pacific. Despite its huge economic importance, studies on the normal biology of the species have lagged far behind the aquacultural studies. Of late a number of new diseases have impacted heavily on the culture of prawns. These include yellowhead rhabdo-like virus (YRV) (Chantanachookhin et al. 1993), white spot bacilliform virus (Wongteerasupaya et al. 1995), Taura syndrome virus (Hasson et al. 1995) and spawner-isolated mortality virus (Fraser \& Owens 1996). Despite the fact that haematology is in widespread use for health monitoring in both humans and domestic animals, little work has been conducted on P. monodon, apart from morphological descriptions of the haemocytes (Tsing et al. 1989). Even though YRV is easily diagnosed because of

\footnotetext{
•E-mail: leigh.owens@jcu.edu.au
}

changes in the haemocytes (Nash et al. 1995), studies on penaeid haemocytes are still lacking. For accurate descriptions of haemocytic changes due to diseases, the normal condition must be known.

Flow cytometry $(F C)$ has been used extensively for monitoring human (Ashmore et al. 1989) and animal (Mackenzie \& Pinder 1987) blood cell populations. FC has been used to study the effect of moult-related changes on the haemocytes of Penaeus japonicus (Sequeira et al. 1995). This paper describes the use of the Cell-Dyn 3000 flow cytometer to distinguish cellular populations within the haemolymph of Penaeus monodon. To do so, it was necessary to assess the effect various host and environmental factors might have on haemocyte populations. These could then be taken into account when monitoring prawn health via the haemocytes.

Primarily designed for mammalian (human) blood, the Cell-Dyn 3000 presents data exclusively in human haematological terms. As the system cannot be altered to present the data in crustacean nomenclature, nucle- 
ated prawn haemocytes were assigned human white blood cell subpopulation terminology. It is important to emphasise that the blood cells of the prawn are in no way correlated or equivalent to the corresponding human white blood cell types to which they were assigned.

\section{MATERIAL AND METHODS}

Terminology. No haemocyte classification for penaeids has been universally accepted, particularly because none of the terms 'hyaline', 'nongranular', nor 'undifferentiated' for the visualised, nongranular haemocytes, as examined by light microscopy, is functiondily or anatomically correct. For consistency, the terminology of Tsing et al. (1989) is used throughout this paper for crustacean haemocytes, but their highly questionable term 'undifferentiated' haemocyte has been replaced with 'nongranular' haemocyte.

Total length was measured from the tip of the rostrum to the tip of the telson. Carapace length was measured from the orbital groove to the posterior edge of the cephalothorax.

Microscopic differential cell counts. For each sample analysed by the flow cytometer, a count of small 'nongranular' haemocytes (SNGH), large nongranular haemocytes (LNGH), small-granular haemocytes (SGH) and large-granular haemocytes (LGH) was performed using a haemocytometer with a light microscope. Also, 2 smears per haemolymph sample were prepared at the time of the bleeding of the prawn and stained with either Giemsa or Diff Quick $^{\text {TM }}$. A pilot study count of 100, 200 and 300 cells was conducted to determine how many cells had to be counted to obtain a true representation of the haemolymph cellular populations.

Haemolymph collection. Prawns were sedated in chilled seawater $\left(7^{\circ} \mathrm{C}\right)$ for $15 \mathrm{~min}$ before cardiac puncture was performed with a 25 gauge needle attached to a $1 \mathrm{ml}$ syringe containing $0.2 \mathrm{ml}$ citrate-EDTA [EDTA $0.01 \mathrm{M}$; trisodium citrate $0.03 \mathrm{M}_{\text {; }}$ citric acid $0.026 \mathrm{M}$; $\mathrm{NaCl} 0.45 \mathrm{M}$; glucose $0.1 \mathrm{M}$, adjusted to $\mathrm{pH} 4.6$ with $1 \mathrm{M} \mathrm{HCl}$ (Söderhäll \& Smith 1983)], and 0.2 to $0.3 \mathrm{ml}$ of haemolymph was extracted.

Haemolymph preparation for Cell-Dyn 3000 analysis. A $1 \mathrm{ml}$ sequestrene tube containing $0.4 \mathrm{ml}$ of prawn haemolymph diluted in an equal amount of citrateEDTA was placed on a mechanical rotator for 2 to 5 min to ensure complete mixing. The tube was then held under the sampling suction syringe of the CellDyn 3000. A $150 \mu$ l sample of haemolymph mixture was aspirated into the machine.

Effect of Cell-Dyn 3000 reagents on Penaeus monodon haemocytes. Three reagents were employed dur- ing each measurement cycle of the Cell-Dyn 3000. Of these, it was the sheath reagent that was mixed with the prawn haemolymph. To ensure that cell integrity was maintained within the flow cycle, an examination of the effects of sheath fluid on the prawn haemolymph was observed prior to Cell-Dyn 3000 analysis.

A juvenile prawn collected from Cardwell, northern Queensland, Australia, for the study on the effect of host parameters on haemocyte numbers (see below) was used for this experiment. A $0.3 \mathrm{ml}$ sample of prawn haemolymph in $0.2 \mathrm{ml}$ citrate-EDTA was mixed with $0.5 \mathrm{ml}$ of Cell-Dyn 3000 sheath reagent. A drop of the mixture was removed and placed on a microscope slide for observation of degranulation or cell lysis using the $100 \times$ objective on an Olympus C.110 light microscope.

Data display of the Cell-Dyn 3000. The Cell-Dyn 3000 records total and differential cell counts to one decimal place in the form, count $\times 10^{3} \mathrm{\mu l}^{-1}$ (i.e. $10^{6} \mathrm{ml}^{-1}$ ), whilst it records differential percentages to 2 decimal points; an increase of 1 significant figure. The prawn haemocyte differential counts were presented in the 5 human cell categories of neutrophils $(\mathrm{N})$, basophils (B), eosinophils (E), lymphocytes (L) and monocytes (M). Relative percentages of each count were also given. Counts lower than $10^{3}$ cells $\mu \mathrm{l}^{-1}$ were recorded as $0.0 \times$ $10^{3}$ cells $\mu^{-1}$.

Correlation between counts from light microscopy and flow cytometry. A total of 40 mixed sex, juvenile prawns $(8.0$ to $15.0 \mathrm{~g})$ were obtained during summer from a 1 ha growout pond at Cardwell. The haemolymph was treated using the standardised procedures listed above for the correlation and to measure effects of sex, length and weight on haemocyte counts.

Variations of haemocyte counts between heterogeneous prawn populations. Juvenile Penaeus monodon populations from 2 different aquacultural facilities and histories, hence heterogeneous populations, were analysed by flow cytometry for variations in haemocyte counts. A total of 40 prawns were collected, 20 from the growout ponds at Cardwell, and 20 from the Australian Institute of Marine Science (AIMS), Townsville, northern Queensland. Prawns from the farm were selected from a 1 ha earth-bottomed pond containing flowthrough unfiltered seawater (35 ppt) aerated by 2 mechanical paddlewheels. Prawns collected from AIMS were held in a shaded, $10 \mathrm{t}$ capacity aboveground tank containing recirculating filtered seawater (36 ppt).

Effect of age on haemocytes. Ten adult (defined as reproductively active) Penaaus monodon ( 47.6 to $62.9 \mathrm{~g}$ weight) and 10 juvenile prawns (defined as showing no gross signs of ovaries or spermatophores) (15.0 to $24.0 \mathrm{~g}$ weight) were collected from the abovementioned sites, bled and analysed by the Cell-Dyn 
3000 flow cytometer to obtain total and differential haemocyte counts.

Seasonal effects on Penaeus monodon haemocyte counts. A total of 40 juvenile prawns, approximately 9 wk post-stocking, were collected from a Cardwell farm in the midwinter month of July. The temperature of the water in these open air growout ponds ranged from 22 to $25^{\circ} \mathrm{C}$ while the salinity varied from 26 to $32 \mathrm{ppt}$. Once in the laboratory, the prawns were held in a $1000 \mathrm{l}$ holding tank containing seawater from the ponds from which they had been collected.

A further 40 juvenile prawns, approximately $9 \mathrm{wk}$ post-stocking, were collected from the same farm within the summer month of January. They were kept in holding tanks under similar conditions to those described above for the winter population. The temperature of the pond water ranged from 27 to $34^{\circ} \mathrm{C}$ and salinity was 21 to $36 \mathrm{ppt}$.

Effect of re-bleeding on haemocyte counts. Ten juvenile Penaeus monodon were maintained within a glass aquarium containing 1701 of seawater equipped with 2 air-lift, under-gravel filters and 1 airstone. Three haemolymph samples $(0.1 \mathrm{ml})$ were sequentially extracted from each prawn at $30 \mathrm{~min}$ intervals. Samples were refrigerated at $4^{\circ} \mathrm{C}$, then analysed by the CellDyn 3000 flow cytometer. With 10 different juvenile prawns, the experiment was repeated using $60 \mathrm{~min}$ intervals.

Statistical analysis. Statistical analysis was performed using the Statistix 4.0 program (Analytical Software, Tallahassee, FL, USA). The distribution of counts was tested for normality using the Wilks-Shapiro test. Abnormally distributed data were transformed using natural logarithm +1 for counts and square root +0.5 for percentages. To permit comparisons between the total nongranular and total granular cell counts from the flow cytometer with the total nongranular and granular cells from microscopic observations, the FC monocytes and lymphocytes were added together to obtain total nongranular (NGH) cells while the eosinophils, basophils and neutrophils were grouped to produce total granular $(\mathrm{GH})$ cell counts. Similarly, the SNGH and LNGH light microscopic counts combined gave total nongranular haemocyte counts, while the addition of the SGH and LGH produced total granular haemocyte counts.

A 1-way ANOVA was used to compare means between 100, 200 and 300 cell microscopic counts determined using a light microscope and to test if there were any differences in haemocyte counts produced by repetitive bleeds.

A paired $t$-test was used to compare the differential counts from the flow cytometer with the differential microscopic counts. A similar t-test was performed on the proportions of total nongranular haemocyte and total granular cells between the FC and microscopic counts.

Two sampled $t$-tests were used to test for differences in cell counts between males and females, 2 heterogenous prawn populations, adult/juvenile prawn populations, summer/winter populations, and the for differences in weight and carapace length of those summer and winter populations.

An unweighted, least sum of squares, linear regression was employed to test for any correlations between weight, total length or carapace length and haemocyte counts.

\section{RESULTS}

\section{Comparison of $\mathrm{FC}$ with conventional haematology}

Effect of Cell-Dyn 3000 reagents on Penaeus monodon haemocytes. No effect of the carrier reagents was observed on the prawn haemocytes during a $1 \mathrm{~h}$ test period.

Microscopic differential haemocyte counts. Statistically there was no difference between means of 100 , 200 and 300 microscope counts of the heterogeneous haemocytes (SNGH: $F=0.36, \mathrm{df}=2,234, \mathrm{p}>0.05$; LNGH: $F=0.14$, df $=2.234, \mathrm{p}>0.05$; SGH: $F=0.39$, $\mathrm{df}=2,234, p>0.05$, LGH: $F=0.25, \mathrm{df}=2,234, \mathrm{p}>0.05$ ). However, less variation in counts was observed with over 200 cells counted. Therefore, subsequent calculations were based on 200 cell counts.

The average total cell count was $23.3 \times 10^{6}$ cells $\mathrm{ml}^{-1}$ $\left(\mathrm{SD}=1.4 \times 10^{6}\right.$ cells $\left.\mathrm{ml}^{-1}, \mathrm{n}=40\right)$. Counts of the heterogeneous cell population (Table 1) demonstrated that nongranular haemocytes comprised the most abundant cell within the prawn haemolymph, accounting for over $80 \%$ of the total haemocytes counted. The LGH were the least frequent cells.

Cell-Dyn 3000 analysis. The average total haemocyte count was $21.0 \times 10^{6}$ cells $\mathrm{ml}^{-1}\left(\mathrm{SD}=0.7966 \times 10^{6}\right.$ cells $\mathrm{ml}^{-1}, \mathrm{n}=40$ ). The heterogeneous haemocyte populations of the prawn haemolymph registered within the 5 classes of human white blood cells, i.e. neutrophils, basophils, eosinophils, lymphocytes and monocytes (Table 1). From this point on, only crustacean haemocyte nomenclature will be used with a subscript to indicate the Cell-Dyn terminology.

Correlation between Cell-Dyn 3000 analysis and microscopic counts. There was no significant difference between the total cell counts computed by the Cell-Dyn 3000 and those recorded microscopically ( $t=$ $1.58, \mathrm{df}=38, \mathrm{p}>0.05)($ Table 1$)$. When comparing the $5 \mathrm{FC}$ categories with the light microscopical categories, only lymphocyte and SNGH $(\mathrm{t}=1.38, \mathrm{df}=38, \mathrm{p}>0.05)$ and neutrophil and SGH $(t=-1.40, \mathrm{df}=38, \mathrm{p}>0.05)$ 
Table 1. Relative percentages of haemocyte types from Penaeus monodon identified by differential cell counts using a light microscope compared to the Cell-Dyn flow cytometer SNGH: small nongranular haemocytes; LNGH: large nongranular haemocytes; SGH: small-granular haemocytes; LGH: large-granular haemocytes; NGH: nongranular haemocytes; GH: granular haemocytes

\begin{tabular}{|c|c|c|c|c|}
\hline \multirow[t]{2}{*}{ Haemocyte } & \multicolumn{2}{|c|}{ Mean percentages } & \multirow{2}{*}{ Cell-Dyn terminology } & \multirow[t]{2}{*}{$\mathrm{p}$} \\
\hline & Microscopic & Flow cytometer & & \\
\hline SNGH & $70.1 \pm 13.9$ & $74.5 \pm 17.4$ & Lymphocyte (L) & $>0.05$ \\
\hline LNGH & $12.6 \pm 15.0$ & $2.2 \pm 3.1$ & Monocyte (M) & $<0.05$ \\
\hline $\mathrm{SGH}$ & $15.6 \pm 17.4$ & $\begin{array}{c}14.5 \pm 14.5 \\
59+56\end{array}$ & Neutrophil (N) & $>0.05$ \\
\hline $\mathrm{LGH}$ & $1.7 \pm 2.2$ & $2.9 \pm 3.4$ & Eosinophil (E) & $<0.05$ \\
\hline \multicolumn{5}{|l|}{ Totals } \\
\hline NGH (SNGH+LNGH) & $82.6 \pm 10.8$ & $76.8 \pm 16.6$ & Nongranular $(\mathrm{L}+\mathrm{M})$ & $>0.05$ \\
\hline $\mathrm{GH}(\mathrm{SGH}+\mathrm{LGH})$ & $17.4 \pm 10.8$ & $23.3 \pm 16.6$ & Granular $(\mathrm{N}+\mathrm{B}+\mathrm{E})$ & $>0.05$ \\
\hline
\end{tabular}

were statistically identical. Therefore, $\mathrm{SGH}_{\mathrm{N}}$ will be used to designate this latter class of cells. Largegranular haemocyte counts were most similar to those of FC granular haemocyte type $\mathrm{E}$ (eosinophil, $\mathrm{GH}_{\mathrm{E}}$ ) but were significantly different $(t=3.034, \mathrm{df}=38, \mathrm{p}<0.05)$. On theoretical light scattering patterns, these 2 cell classes should be similar.

Further analysis was performed on the combined nongranular and granular classes as outlined above. There were no significant differences between the total nongranular haemocytes of the FC and the total nongranular cells within the microscopic counts $(t=$ 0.71 , df $=38, \mathrm{p}>0.05$ ). Nor was there a difference between the total FC granular cell counts with the total microscopic granular cell counts $(t=0.41$, df $=38, p>$ $0.05)$. The nongranular haemocytes were the most abundant cells recorded by the flow cytometer ranging from 60 to $93 \%$ of total cells, and conversely, granular cells ranged from 7 to $40 \%$.

\section{Effect of host and environmental factors on haemocyte counts}

Influences of sex, length and weight on haemocyte counts. Total haemocyte counts (THC) $(F=1.54$, $\mathrm{df}=1,39, \mathrm{p}>0.05)$ and granular haemocyte counts $(F=1.77, \mathrm{df}=1,39, \mathrm{p}>0.05)$ within male and female prawns were not significantly different. Nongranular haemocytes were significantly different $(F=4.56$. $\mathrm{df}=1,39, \mathrm{p}<0.05$ ) between the sexes, with females having higher levels than males.

Carapace length had no bearing on THC $(F=1.85$, $\mathrm{df}=1,39, \mathrm{p}>0.05)$ nor did weight $(F=2.51, \mathrm{df}=1,39$, $\mathrm{p}>0.05)$. Total length measurements had a significant effect on THC $(F=4.60$, df $=1,39, p<0.05)$ and NGH $(F=4.28, \mathrm{df}=1,39, \mathrm{p}<0.05)$. After adolescence, female prawns are larger in total length than their male counterparts (based on prawns of the same age); the increase in haemocyte quantities with greater proportions of NGH in largor animals is, therefore, a link between sex and sexual dimorphism (size, as measured by total length) of the prawn.

Juvenile versus adult populations. All haemocyte counts were similar for the juvenile and adult prawns $\left(\mathrm{THC}_{;} F=2.19\right.$, df $\left.=1,19, \mathrm{p}>0.05\right)\left(\mathrm{NGH}_{;} F=4.57\right.$, $\mathrm{df}=1.19, \mathrm{p}>0.05)(\mathrm{GH} ; F=1.99, \mathrm{df}=1,19, \mathrm{p}>0.05)$. As this result is incongruous compared to results in the previous section, it needs further explanation. Examination of the $F$ values for the NGH suggest it is possibly the lack of degrees of freedom (i.e. sample size) in the comparison of adults and juveniles that has made this anomaly surface.

Heterogeneous prawn populations. No substantial differences in THC ( $F=1.61$, df $=1,39, p>0.05)$ and differential haemocyte $\left(\mathrm{NGH}_{i} F=1.98\right.$, df $=1,39, \mathrm{p}>$ 0.05) $(\mathrm{GH} ; F=1.05, \mathrm{df}=1,39, \mathrm{p}>0.05)$ counts existed between the 2 different prawn populations of Cardwell and Townsville.

Seasonal variations. There were no differences in carapace length between the summer and winter populations $(F=1.7 \mathrm{df}=1.39, \mathrm{p}>0.05)$. However, there was a difference between the weights of the 2 populations $(F=4.77$, df $=1,39, p<0.05)$, with prawns that were sampled in the summer $(23 \pm 5.5 \mathrm{~g})$ being twice as heavy as those sampled in winter $(12.5 \pm 2.5 \mathrm{~g})$. At the time of the bleed, the winter prawns were noted to be underweight and not feeding properly.

No notable differences existed for THC $(F=1.38$, $\mathrm{df}=1,39, \mathrm{p}>0.05), \mathrm{SGH}_{\mathrm{N}}$ or $\mathrm{GH}$ between seasons (Table 2). However, significant differences were observed between the winter and the summer prawn populations within the $\mathrm{NGH}, \mathrm{GH}_{\mathrm{E}}$ and $\mathrm{GH}_{\mathrm{B}}$ categories with the winter prawns having $89.44,1.00$ and $0.99 \%$ respectively, whilst the summer prawns had $76.75,2.89$ and $5.86 \%$ respectively.

Repetitive bleeding effects on haemocyte counts. Bleeds of $0.1 \mathrm{ml}$ were conducted at 30 min intervals, 
Table 2. Percentages of the different types of haemocytes in Penaeus monodon between seasons. NGH: nongranular haemocytes; SGH: smallgranular haemocytes; GH: granular haemocytes; THC: total haemocyte counts

\begin{tabular}{|lrrrrr|}
$\begin{array}{l}\text { Haemocyte } \\
\text { type }\end{array}$ & $\begin{array}{c}\text { Winter mean } \\
(\%)\end{array}$ & $\begin{array}{c}\text { Summermean } \\
(\%)\end{array}$ & $F$ & df & $p$ \\
\hline $\mathrm{NGH}$ & 89.44 & 76.75 & 2.82 & 1,39 & $<0.05$ \\
$\mathrm{GH}_{\mathrm{B}}$ & 0.99 & 5.86 & 3.61 & 1,39 & $<0.05$ \\
$\mathrm{SGH}_{N}$ & 7.86 & 14.50 & 1.13 & 1.39 & $>0.05$ \\
$\mathrm{GH}_{\mathrm{E}}$ & 1.00 & 2.89 & 5.56 & 1,39 & $<0.05$ \\
Total GH & 9.85 & 23.23 & 1.13 & 1,39 & $>0.05$ \\
$\mathrm{THC}$ & & & 1.38 & 1.39 & $>0.05$ \\
\hline
\end{tabular}

positive haemocytes (presumptive dead cells) and they reported results almost entirely in percentage figures. Their strategy was to configure their FC to find only 3 populations of cells that could be ascribed to the 3 haemocyte types found by light microscopy, namely hyaline (herein NG), small granular and large granular cells. During moult stages $B$ and D1, hyaline, SGH and LGH were 40 to $44 \%, 31$ to $32 \%$ and 25 to $29 \%$ respectively compared with 83,15 and $3 \%$ respectively for $P$. monodon in this study.

Of the population factors examined, only sex had a significant effect on NGH counts.

and there was a dramatic decrease in the total haemocyte count of Penaeus monodon at the third bleed ( $F=$ 6.39 , df $=2,29, p<0.05$ ) (Table 3 ). There were no substantial differences in proportional haemocyte counts $(\mathrm{NGH} ; F=2.20, \mathrm{df}=2,29, \mathrm{p}>0.05)(\mathrm{GH} ; F=1.93, \mathrm{df}=$ $2,29, \mathrm{p}>0.05)\left(\mathrm{G}_{\mathrm{B}} ; F=1.72, \mathrm{df}=2,29, \mathrm{p}>0.05\right)\left(\mathrm{SGH}_{\mathrm{N}} ;\right.$ $F=1.25, \mathrm{df}=2,29, \mathrm{p}>0.05)\left(\mathrm{G}_{\mathrm{E} ;} F=0.42, \mathrm{df}=2,29, \mathrm{p}>\right.$ $0.05)$ for the three $30 \mathrm{~min}$ bleeds.

For bleeds at 60 min intervals, total counts again decreased with the third repetitive bleed $(F=5.16$, df $=$ $2,29, p<0.05$ ) (Table 3). The fact that both the 30 and 60 min interval tests gave similar results suggested that the number of bleeds-not the time intervalcompromised the prawn's haemocyte count. However, proportional counts changed at the third rebleed of the 60 min experiment for $\mathrm{GH}_{\mathrm{E}}(F=5.27, \mathrm{df}=2,29, \mathrm{p}<$ $0.05)$ and $\mathrm{SGH}_{\mathrm{N}}(F=3.70, \mathrm{df}=2,29, \mathrm{p}<0.05)$ (Table 4). There was no significant differences in the overall proportion of $\mathrm{GH}(F=2.09$, df $=2,29, \mathrm{p}>0.05)$ or $\mathrm{NGH}$ $(F=1.53, \mathrm{df}=2,29, \mathrm{p}>0.05)$.

\section{DISCUSSION}

FC has potential as a tool in prawn health studies as total, granular and nongranular haemocyte counts using both the FC and light microscope were statistically similar. THC, $\mathrm{SGH}_{\mathrm{N}}$ and $\mathrm{SGH}$ were identical and probably LGH and $\mathrm{GH}_{\mathrm{E}}$ can be usefully compared. $\mathrm{GH}_{\mathrm{B}}$ were included with the granular series for analysis in this study; the raw counts suggest the $\mathrm{GH}_{\mathrm{B}}$ probably should be included in future studies with that which the eye recognises as nongranular cells. These $\mathrm{GH}_{\mathrm{B}}$ were less complex cells and were probably haemocytes that contained very small granules, detectable only by electron microscopy (Hose \& Martin 1989).

Unfortunately, the results of the FC study of haemocytes from Penaeus japonicus done by (Sequeira et al. 1995) are difficult to compare with the results from our study. Their methodology excluded propidium iodide-
Likewise, an indirect measure of sex and sexual dimorphism, total length, had an significant effect on NGH and THC. Total length is a measure of sexual dimorphism as, generally, female Penaeus monodon are longer than their male counterparts (Liao 1989). Similarly, Sequeira et al. (1995) observed sex related changes in haemocyte composition of $P$. japonicus throughout the moult cycle. Likewise, Vargas-Albores et al. (1992) found that size and maturity had a significant negative effect on erythrocyte haemagglutination ability (humoral response) of Penaeus stylirostris which they attributed to a postulated increased role of the cellular response in the larger prawns. Female prawns lay down ovaries in the region of their dorsal

Table 3. Total haemocyte counts (THC) upon successive bleedings of Penaeus monodon. Comparisons were carried out by least significant difference analysis of THC $\left(\times 10^{6}\right.$ cells $\mathrm{ml}^{-1}$ ) for bleeds at 30 and 60 min intervals. There was no significant difference $(p>0.05)$ between the groups with the same superscript

\begin{tabular}{|ccc|}
\hline $\begin{array}{c}\text { Bleed time } \\
\text { (min) }\end{array}$ & $\begin{array}{c}\text { THC } \\
\text { min series }\end{array}$ & $\begin{array}{c}\text { THC } \\
60 \text { min series }\end{array}$ \\
\hline 0 & $21.3^{\mathrm{a}}$ & $20.6^{\mathrm{c}}$ \\
30 & $19.9^{\mathrm{a}}$ & \\
60 & $9.7^{\mathrm{b}}$ & $19.8^{\mathrm{c}}$ \\
120 & & $9.4^{\mathrm{d}}$ \\
\hline
\end{tabular}

Table 4. Least significant difference analysis of transformed percentages of granular haemocytes type $\mathrm{E}\left(\mathrm{GH}_{\mathrm{E}}\right)$ and smallgranular haemocytes type $\mathrm{N}\left(\mathrm{SGH}_{\mathrm{N}}\right)$ for bleeds of Penaeus monodon at $60 \mathrm{~min}$ intervals. There was no significant difference $(p>0.05)$ between the groups with the same superscript

\begin{tabular}{|ccc|}
\hline $\begin{array}{c}\text { Time postbleed } \\
\text { (min) }\end{array}$ & $\begin{array}{c}\text { Mean \% } \\
\mathrm{GH}_{\mathrm{E}}\end{array}$ & $\begin{array}{c}\text { Mean \% } \\
\mathrm{SGH}_{\mathrm{N}}\end{array}$ \\
\hline 0 & $1.96^{\mathrm{a}}$ & $4.84^{\mathrm{c}}$ \\
60 & $1.96^{\mathrm{a}}$ & $6.76^{\mathrm{cd}}$ \\
120 & $5.29^{\mathrm{b}}$ & $13.69^{\mathrm{d}}$ \\
\hline
\end{tabular}


musculature. During this process, the dorsal muscle is resorbed by haemocytes as are the remains of spent ovaries between maturation cycles. These physiological changes and the extended role for the haemocytes in females were probably reflected in the haemocyte changes registered by FC. Consequently in haemocyte studies, the sex of prawns should be analysed as a cofactor.

Cornick \& Stewart (1978) reported sex did not influence the differential haemocyte counts in the lobster Homarus americanus. They did, however, find that the $\mathrm{NGH}$ and the GH percentages varied significantly amongst lobster populations. This may be a physiological difference between prawns and lobsters, or perhaps the discrepancy may reflect differing health status of their lobster populations.

As expected, sequential bleeding of prawns $(0.1 \mathrm{ml}$ of haemolymph) produced a decrease in total haemocyte numbers. Although there was no dramatic decrease in total haemocyte numbers at the second bleed, there was at the third. Thus, rapid repetitive bleeding is not advisable, since a substantial decrease in the total haemocyte count could compromise the immunocompetence of the prawn and reduce its resistance to infections (Persson et al. 1987). For example, Thörnqvist \& Söderhäll (1993) have reported that the loss of haemocytes did not cause higher mortalities in healthy crayfish, but did amongst those carrying infectious agents or parasites

Although total haemocyte counts were comparable between summer and winter seasons, significant changes in the differential haemocyte proportions were found. Winter stocks had increased quantities of nongranular haemocytes accompanied by substantial reductions in granular haemocytes $B$ and $E$. This was unlikely to be a direct climatic-induced variation as all other parts of this study suggested that prawn haemocyte levels were within the physiological limits of this species. These changes may have been diseaserelated since the winter prawns were considered to be of an inferior quality prior to stocking of ponds (N. Moore pers. comm.). Furthermore, there were significant weight differences between the summer and winter populations even though their carapace lengths were similar, suggesting starvation because of a health problem. Similar total haemocyte counts between seasons indicated that there was no haemocytopenia, but there were shifts in the differential counts. A significant decline in the various granular haemocyte types coincident with an increase in nongranular haemocytes indicated that some degranulation may have taken place. Intact, degranulated granular cells would be registered by the Cell-Dyn 3000 as nongranular haemocytes. The actual degranulation of intracytoplasmic granules is highly significant, indicating release of the prophenoloxidase system resulting from the recognition of the introduction of foreign material (Söderhäll \& Smith 1983, Johansson \& Söderhäll 1989).

Acknowledgements. Dr Paul Turner of the Anton Breinl Centre for Tropical Medicine is thanked for training and access to the Cell Dyn 3000 flow cytometer without which this study would not have been possible. Dr Henry Lau of Consulting Pathologists Pty Ltd is also thanked for access to his Cell Dyn 3000 flow cytometer.

\section{LITERATURE CITED}

Ashmore LM, Shopp GM, Edwards BS (1989) Lymphocyte subset analysis by flow cytometry. J Immunol Meth 118:209-215

Chantanachookhin C, Boonyaratpaìn S, Kasornchandra J, Direkbusarakom S, Ekpanithanpong U, Supamataya K, Sriurairatana S, Flegel TW (1993) Histology and ultrastructure reveal a new granulosis-like virus in penaeus monodon affected by yellow-head disease. Dis Aquat Org 17:145-157

Cornick JW, Stewart JE (1978) Lobster (Homarus americanus) hemocytes: classification, differential counts, and associated agglutination activity. J Invertebr Pathol 31:194-203

Fraser CA, Owens L (1996) Spawner-isolated mortality virus from Australian Penaeus monodon. Dis Aquat Org 27: $141-148$

Hasson K, Lightner DV, Poulos BT, Redman RM, White BL, Brock JA, Bonami JR (1995) Taura syndrome in Penaeus vannamei: demonstration of a viral etiology. Dis Aquat Org 23:115-126

Hose JE, Martin GG (1989) Defence functions of the granulocytes in the ridgeback prawn Sicyonia ingentis. J Invertebr Path 53:335-346

Johansson MW, Söderhäll K (1989) Cellular immunity in crustacea and the proPO system. Parasitol Today 5:1.71-176

Liao IC (1989) Penaeus monodon culture in Taiwan through two decades of growth. Int J Aquat Fish Tech 1:16-24

Mackenzie NM, Pinder AC (1987) Flow cytometry and its application in veterinary medicine. Res Vet Med 42 $131-139$

Nash G, Arkarjamon A, Withyachumnarnkul B (1995) Histological and rapid haemocytic diagnosis of yellow-head disease in Penaeus monodon. Shariff M, Arthur JR, Subasinghe R (eds) Diseases in Asian Aquaculture II. Fish Health Section, Asian Fisheries Society, Manila, p 89-98

Persson M, Cerenius L, Soderhall K (1987) The influence of the haemocyte number on the resistance of the freshwater crayfish, Pacifastacus leniusculus Dana, to the freshwater fungus Aphanomyces astaci. J Fish Dis 10:471-477

Sequeira T, Vilanova M, Lobo-Da-Cunha A, Baldaia L, ArlaChaves $M$ (1995) Flow cytometric analysis of molt-related changes in haemocyte type in male and female Penaeus japonicus. Biol Bull (Woods Hole) 189:376-380

Söderhäll K, Smith VJ (1983) Separation of the haemocyte populations of Carcinus maenas and other marine decapods and prophenoloxidase distribution. Dev Comp Immunol 7:229-239

Thörnqvist PO, Söderhäll K (1993) Psorospermum haeckeli and its interaction with the crayfish defence system. Aquaculture 117:205-213

Tsing A, Arcier JM, Brehelin M (1989) Hemocytes of penaeid and palaemonid shrimps: morphology cytochemistry and hemograms. J Invertebr Pathol 53:64-77 
Vargas-Albores F, Guzman A, Ochoa JL (1992) Size-dependent haemaggluting activity in the haemolymph from sub-adult blue shrimp (Penaeus stylirostris Stimpson), Comp Biochem Physiol 103A:487-491

Wongteerasupaya C, Vickers JE, Sriurarratana S, Nash GL,

Editorial responsibility: James Stewart

Dartmouth, Nova Scotia, Canada
Akarajamorn A, Boonsaeng V, Panyim S, Tassanakajon A, Withyachumnarnkul B, Flegel TW (1995) A non-occluded, systemic baculovirus that occurs in cells of ectodermal and mesodermal origin and causes high mortality in the black tiger prawn Penaeus monodon. Dis Aquat Org 21:69-77

Submitted: October 8, 1996; Accepted: August 19, 1997 Proofs received from author(s): November 6, 1997 